\author{
Andrzej Kozina \\ Katedra Procesu Zarządzania \\ Uniwersytet Ekonomiczny w Krakowie
}

\title{
Organizowanie zespołu negocjacyjnego
}

\section{Streszczenie}

Celem artykułu jest usystematyzowanie najważniejszych problemów związanych $\mathrm{z}$ organizowaniem zespołu reprezentującego przedsiębiorstwo w różnego rodzaju negocjacjach (zarówno wewnętrznych, jak i zewnętrznych) oraz przedstawienie zasad (zaleceń, wskazań, reguł) rozwiązywania tych problemów. Tworzenie tego rodzaju zespołu stanowi jedno z najistotniejszych działań realizowanych w procesie planowania negocjacji w firmie. W kolejnych częściach artykułu omówiono następujące problemy dotyczące organizowania zespołu negocjacyjnego oraz zasady rozwiązywania tych problemów: 1) podjęcie decyzji o powołaniu zespołu negocjacyjnego, 2) wybór jego formy organizacyjnej, 3) określenie jego liczebności, 4) ustalenie kryteriów doboru jego członków, 5) określenie ról w zespole, 6) zlecanie zadań i ich podział pomiędzy jego członków, 7) delegowanie uprawnień decyzyjnych.

Słowa kluczowe: negocjacje w przedsiębiorstwie, zespół negocjacyjny, planowanie operacyjne negocjacji, organizowanie zespołu negocjacyjnego.

\section{Wprowadzenie}

Celem artykułu jest usystematyzowanie najważniejszych problemów związanych z organizowaniem zespołu reprezentującego przedsiębiorstwo w różnego rodzaju negocjacjach (zarówno wewnętrznych, jak i zewnętrznych) oraz przedstawienie zasad (zaleceń, wskazań) rozwiązywania tych problemów. Tworzenie tego rodzaju zespołu stanowi jedno z najistotniejszych działań realizowanych 
w procesie planowania negocjacji w firmie. Najogólniej proces ten (w szerokim znaczeniu) obejmuje trzy fazy: identyfikację i analizę przednegocjacyjną, ustalenie zakresu i strategii negocjacji (planowanie w ścisłym znaczeniu) oraz planowanie operacyjne negocjacji. Celem tej ostatniej jest zapewnienie odpowiednich warunków do prowadzenia negocjacji, głównie poprzez dobór właściwych reprezentantów firmy w negocjacjach.

W literaturze przedmiotu najczęściej mamy do czynienia z interpretowaniem negocjacji jako: procesu decyzyjnego, metody kierowania konfliktem i osiągania porozumienia, wzajemnej zależności partnerów oraz procesów: komunikowania się, wymiany i tworzenia wartości [Lewicki i in. 2005, s. 17 i nast.; Rządca 2003, s. 23 i nast.; Kozina 2012, s. 21-24]. Najistotniejsza jest pierwsza z wymienionych interpretacji, czyli negocjacji jako interakcyjnego procesu podejmowania decyzji, który w fazie przygotowawczej strony realizują niezależnie od siebie (ze względu na cele). Następnie dokonują wzajemnych uzgodnień w zakresie dwóch par zbiorów: alternatyw rozwiązań i kryteriów oceny określonych wstępnie dla każdej ze stron z osobna w efekcie analizy problemu decyzyjnego. Wybierają kryteria, mając na uwadze ich interesy i ustalają zbiór alternatyw jako część wspólną wyjściowych opcji.

Negocjacje w przedsiębiorstwie obejmują wszelkie ich rodzaje wynikające z jego istoty jako szczególnego rodzaju organizacji, zarówno te przypadki, w których stanowi ono środowisko negocjacji, jak i te, przy których jest ich stroną. Rozważane negocjacje mogą więc być prowadzone pomiędzy wewnętrznymi grupami interesów, np. pracodawcami i pracobiorcami, właścicielami i menedżerami, jak i pomiędzy reprezentantami firmy z interesariuszami zewnętrznymi, np. dostawcami, odbiorcami, kooperantami. Negocjacje są zatem instrumentem zarządzania firmą poprzez kształtowanie jej relacji z otoczeniem i wewnętrznych warunków współdziałania.

Przy tworzeniu zespołu negocjacyjnego rozwiązywane są następujące problemy:

- podjęcie decyzji o powołaniu zespołu negocjacyjnego,

- wybór jego formy organizacyjnej,

- określenie jego liczebności,

- ustalenie kryteriów doboru jego członków,

- określenie ról w zespole,

- zlecanie zadań i ich podział pomiędzy jego członków,

- delegowanie uprawnień decyzyjnych.

Dodatkowym, nierozważnym tutaj zagadnieniem, związanym z doborem członków zespołu oraz określaniem ich ról i zadań, jest analiza wymaganego potencjału ich wiedzy, zdolności i umiejętności oraz cech osobowości [Kozina 2001]. Celem rozwiązywania tych problemów można wykorzystać typowe zasady zarządzania, a zwłaszcza organizacji pracy zespołów [Barrett 1994, Jaques 1992] 
i rozwiązania modelowe, wynikające z doświadczeń, proponowane w literaturze, np. [Brooks i Odiorne 1984, s. 159-171; Dąbrowski 1991, s. 33-34, 62-63; Nęcki 2000, s. 189-192; Schoonmaker 1989, s. 210-234; Thompson 2001, s. 210 i nast.].

\section{Wskazania co do powoływania zespołu negocjacyjnego}

Przed stworzeniem takiego zespołu niezbędna jest wstępna analiza wymagan (merytorycznych i organizacyjnych) dotyczących negocjacji wynikających z ustaleń planistycznych co do ich zakresu, celów, strategii, kontekstu itp. oraz uzasadniających ewentualne angażowanie zespołu zamiast indywidualnego reprezentanta. Podjęcie decyzji o tworzeniu zespołu jest korzystne, gdy [Mannix 2005, Thompson 2001, s. 211; Walker i Harris 1995, s. 71-73]:

- negocjacje są złożone i wymagają zróżnicowanej wiedzy i umiejętności lub fachowego doradztwa,

- tkwi w negocjacjach duży potencjał szukania kreatywnych, integrujących rozwiązań,

- reprezentowane są zróżnicowane stanowiska i interesy,

- chce się okazać swoją siłę wobec drugiej strony, np. w negocjacjach międzynarodowych, w przypadku których występowanie zespołów jest normą,

- pragnie się dać do zrozumienia drugiej stronie, że negocjacje są traktowane bardzo poważnie, jak np. przy okazji fuzji i przejęć,

- ma się do dyspozycji osoby godne zaufania i szacunku,

- posiada się wystarczający czas do zorganizowania i koordynacji pracy zespołu.

Powoływanie reprezentantów może być mniej lub bardziej formalne, zwykle na podstawie wyboru albo mianowania - wtedy mają oni silniejszą pozycję, większą swobodę decyzji, więc mogą efektywniej działać [Brooks i Odiorne 1984, s. 167].

Istotnym utrudnieniem przy powoływaniu zespołu i ustalaniu jego składu, zadań itp. jest opieranie się na przybliżonym rozpoznaniu sytuacji, zwłaszcza pozycji partnera (np. celów, interesów, założeń). Trudno np. jednoznacznie rozstrzygnąć, czy określenie liczebności zespołu ma następować przed czy po ustaleniu ról jego członków. Może to powodować zmiany ustalonego wstępnie składu zespołu po konfrontacji założeń obu stron, a nawet w trakcie negocjacji, np. wycofanie kontrowersyjnego negocjatora, zaangażowanie dodatkowego eksperta itp. [Hiltrop i Udall 1995, s. 81] lub poszerzenia zespołu, aby pokazać partnerowi, że dany etap negocjacji ma szczególne znaczenie. Niezbędne mogą być formalne uzgodnienia między stronami przed podjęciem negocjacji, co do liczebności zespołu, zasad udziału mediatora czy konsultantów itp. W praktyce wzajemne „docieranie się” reprezentantów ma miejsce przed rozpoczęciem negocjacji, w trakcie poprzedzających je spotkań, prac analitycznych czy ewentualnych szkoleń. 


\section{Zalecenia co do wyboru formy organizacyjnej zespołu}

Z organizacyjnego punktu widzenia zespół odpowiedzialny za prowadzenie negocjacji przyjmuje zwykle jedną z dwóch typowych form.

1. Zespół zadaniowy (projektowy) - formalne wyodrębniony z ogólnej (całościowej) struktury firmy (sztabowo-liniowej, dywizjonalnej, sieciowej itp.), o charakterze doraźnym (czasowym), tj. do realizacji określonego przedsięwzięcia, po którego zakończeniu ulega rozwiązaniu. Forma taka, jako specyficzny projekt, doskonale nadaje się do negocjacji [Kozina 2014]. Po dokładnym sformułowaniu zadania (celów i założeń negocjacji oraz wymagań co do ich przebiegu) powołuje się kierownika zespołu negocjacyjnego, który dobiera sobie jego członków specjalistów z wymaganych dziedzin. Zespół podlega bezpośrednio kierownictwu wyższego szczebla nadzorującego daną dziedzinę działalności, w ramach której odbywają się negocjacje, i posiada własną wewnętrzną strukturę. W zależności od zakresu i specyfiki realizowanego przedsięwzięcia może mieć formę luźnego zespołu kierowanego przez koordynatora zadania (dla prostszych negocjacji) albo zespołu zadaniowego z pełnym oddelegowaniem i podporządkowaniem jego członków kierownikowi zespołu (dla ważniejszych negocjacji), albo też zespołu kierowanego przez grupę decyzyjno-koordynacyjną (dla negocjacji o złożonym zakresie i (lub) dużym znaczeniu).

2. Zespół wirtualny - składający się z wewnętrznych specjalistów negocjacyjnych (wykonawców i liderów), pełniących różne funkcje w obrębie organizacji tradycyjnej, powołany w celu wykonania konkretnego zlecenia (procesu negocjacyjnego). Członkowie zespołu angażują w realizację tego zlecenia, przekraczającego ich tradycyjne zakresy zadań, niezbędne kompetencje kluczowe, na podstawie których są dobierani, celem optymalizacji efektów pracy zespołu (najlepsi negocjatorzy w firmie). Rozwiązanie z jednej strony zbliżone do poprzedniego, gdyż w obu przypadkach zespół ponosi pełną odpowiedzialność w ramach wyznaczonych celów związanych z przygotowaniem, realizacją i wdrożeniem przedsięwzięcia (negocjacji). Zespół wirtualny jednak różni się od zadaniowego tym, że ten pierwszy, nie będąc stałym elementem całościowej struktury organizacyjnej firmy, nie musi mieć również formalnego charakteru, lecz jest tworzony spontanicznie, niezauważalnie, działa niejako „w uśpieniu”. Jego członkowie mają zawsze formalnie określone stanowiska organizacyjne, a w ramach zakresu ich zadań mieszczą się działania związane z realizacją procesów negocjacyjnych.

Przy powoływaniu zespołu negocjacyjnego wykorzystuje się zatem typowe zasady tworzenia tego rodzaju rozwiązań strukturalnych, prezentowane w literaturze przedmiotu, nie omawiając szczegółowo ich istoty, zalet i wad [Doskonalenie struktury... 1991, s. 20 i nast.; Nalepka i Kozina 2007, s. 85 i nast.]. 
To, którą z omówionych form organizacji zespołu negocjacyjnego się stosuje, rozstrzyga ranga i złożoność zakresu konkretnych negocjacji, związane zwykle z przewidywanym czasem ich prowadzenia. W przypadku negocjacji o dużym znaczeniu, strategicznych i długotrwałych, np. w zakresie aliansu strategicznego czy z kluczowym inwestorem, preferowany powinien być zespół zadaniowy, którego formalny charakter umożliwia także precyzyjne ustalenie zakresów odpowiedzialności za realizację negocjacji oraz efektywniejszy nadzór nad ich przebiegiem. Dla negocjacji rutynowych, powtarzalnych, krótkotrwałych i niewymagających ścisłego nadzoru, np. przy typowych transakcjach handlowych, czy w ramach stałych umów o współpracę, bardziej właściwy jest zespół wirtualny. W tym drugim przypadku można nawet mówić nie o projektowych, ale o procesowych zespołach negocjacyjnych ze względu na powtarzalność procesów negocjacyjnych i możliwość ich utrwalenia w postaci procedur.

\section{Zasady ustalania liczebności zespołu}

W przypadku ustalenia liczebności zespołu trudno podać „złotą regułę”. Trzyosobowy zespół jest uważany za idealny, a z pewnością nie powinien on liczyć więcej niż pięć osób [Fowler 2001, s. 54; Brooks i Odiorne 1984, s. 168; Thompson 2001, s. 211]. Przeważnie kompletuje się składy 3-5-7-osobowe, co zapewnia kameralność warunków i sprzyja wspólnemu, twórczemu poszukiwaniu rozwiązań [Zbiegień-Maciąg 2001, s. 30]. Tylu powinno być reprezentantów, aby zabezpieczyć każdy omawiany aspekt, ale równocześnie nie powinno być ich zbyt wielu [Nęcki 2000, s. 189-190; Walker i Harris 1995, s. 71-73].

Niekiedy uważa się, że utrudnienie dla negocjatora może stanowić większa liczebność zespołu jednej ze stron. Wynika stąd „dyplomatyczne” zalecenie równej liczby reprezentantów stron [Dąbrowski 1991, s. 34]. Dobry zespół nie musi być taki sam, jak zespół drugiej strony. Liczba nie zapewnia bezpieczeństwa, tylko zwiększa koszty. Ważne kryteria doboru stanowią także: jednoznaczność ról, sposób budowania większości i rozpiętość kierowania [Brooks i Odiorne 1984, s. 168-169].

Zwiększanie wielkości zespołu wynika z chęci wykorzystania jednej z głównych zalet pracy grupowej, tzn. możliwości osiągnięcia efektu synergicznego wiedzy i umiejętności jednostek. Wzrasta wtedy jednak prawdopodobieństwo wystąpienia jednej z najtrudniejszych do pokonania wad pracy zespołowej, jaką są problemy koordynacji jednostkowych działań, wzrastające zwykle nieproporcjonalnie do liczby osób oraz związane z tymi problemami kłopoty w porozumiewaniu się i tworzeniu klimatu zaufania. Im większy zespół, tym trudniej jest kontrolować jego szefowi poszczególne odcinki i koordynować pracę całości. 
W krańcowych przypadkach może to prowadzić do większej koncentracji na tym, jak negocjator jest odbierany przez własną grupę niż na tym, jak negocjuje [Nęcki 2000, s. 190]. Ważna zatem jest możliwość zebrania masy krytycznej wiedzy bez konieczności tworzenia zbyt dużego zespołu: im większy zespół, tym trudniejsza i kosztowniejsza jest jego koordynacja [Watkins 2005, s. 181; Thompson 2001, s. 211]. Zgromadzenie zbyt dużego zespołu grozi nie tylko brakiem koordynacji między uczestnikami, ale nawet możliwością powstania różnicy zdań wewnątrz takiego zespołu w trakcie prowadzenia negocjacji [Fowler 2001, s. 54].

\section{Kryteria doboru członków zespołu}

Zasadnicze przesłanki doboru reprezentantów stanowią ich kompetencje fachowe (merytoryczne) oraz doświadczenie w zakresie samych negocjacji i specjalistycznych zagadnień będących ich przedmiotem. Należy także wziąć pod uwagę wiele czynników kształtujących sytuację negocjacyjną, w szczególności:

- specyfikę, rodzaj negocjacji, stopień złożoności i trudności ich zakresu,

- wagę (istotność) negocjowanych zagadnień i założonych celów,

- znaczenie, w tym przewidywaną wartość potencjalnej transakcji,

- narzędzia negocjacji (strategię, zasady, techniki, oferty, argumenty itd.).

Istotne znaczenie może mieć także status (pozycje, stanowiska) reprezentantów, adekwatne do zakresu odpowiedzialności i znaczenia danej sytuacji negocjacyjnej. Należy również uwzględnić różne czynniki o charakterze organizacyjnym, a zwłaszcza umiejętność pracy zespołowej i współdziałania oraz możliwość efektywnego koordynowania i kontrolowania działań jednostkowych i całego zespołu, a także kryteria związane z umiejętnością współżycia [Nęcki 2000, s. 190-191], takie jak:

- dopasowanie - wzajemny szacunek członków zespołu, jednoznacznie przypisane role i obowiązki (by każdy wiedział, za co jest odpowiedzialny), wydawanie poleceń poszczególnym członkom, a nie grupie jako całości,

- wewnętrzna równowaga - pod względem zdolności i znajomości poszczególnych zagadnień - liczne badania wskazują, że zespoły dobrze dobrane, choć o przeciętnych uzdolnieniach umysłowych, uzyskują znacznie lepsze rezultaty niż zespoły niedopasowane (niezgranych ,gwiazd"),

- zaufanie do kompetencji i moralności (uczciwości) członków zespołu,

- uznanie ze strony przeciwnej (szacunek i aprobata) - pozytywne nastawienie znacznie poprawia atmosferę i tendencję do kooperacji, ugody,

- role w zespołach - możliwość obsadzenia najczęściej występujących ról.

Ponadto przy doborze reprezentantów w negocjacjach brane są pod uwagę (przed przedstawicieli różnych kultur) czynniki indywidualne, takie jak: doświad- 
czenie w prowadzeniu negocjacji, status, walory osobiste, wiek i płeć [Dąbrowski 1991, s. 58].

\section{Reguły określania ról w zespole}

Najważniejsza zasada jest taka, aby role te były jak najbardziej zgodne z predyspozycjami reprezentantów zarówno pod względem osobowości, jak i zawodu. Podstawowym kryterium określania tych ról powinny być kompetencje merytoryczne adekwatne do zakresów zadań pracowników.

Tabela 1 zawiera zestawienie ról wybranych spośród proponowanych w literaturze. Mają one ono charakter uniwersalny, tj. odnoszą się do różnego rodzaju negocjacji, i modelowy - wskazują funkcje możliwe do zrealizowania w ich trakcie. Nie należy ich jednak interpretować dosłownie, tzn. zakładać, że powinno się angażować dokładnie tyle osób, ile jest możliwych ról. Bardzo często nie jest to niezbędne, np. ze względu na ograniczony zakres merytoryczny i (lub) niski stopień trudności negocjacji, brak możliwości (np. w małej firmie). Ze względu na czasochłonność negocjacji, a więc ich koszty, konieczna może być redukcja wielkości zespołu do ludzi, których udział jest rzeczywiście niezbędny, ograniczając uczestnictwo ekspertów do ściśle określonych momentów dyskusji, zwłaszcza bez niepotrzebnego roztrząsania szczegółów technicznych [Kennedy 1998, s. 240]. Pewne funkcje mogą być realizowane łącznie przez tych samych członków zespołu (np. w zakresie obserwacji i analizy), inne nie (np. „twardego” i „miękkiego faceta”, czy kierownika z innymi rolami). Zalecane kombinacje ról to np. „twardy facet” i analityk informacji, a takie, których należy unikać, to np. kierownik z rzecznikiem [Schoonmaker 1989, s. 229-231].

Biorąc pod uwagę przedstawione typologie ról negocjacyjnych, wydaje się, że celowe jest uwzględnienie następujących spośród nich:

- przełożony (decydent, zleceniodawca) - uprawniony do podejmowania decyzji w zakresie dziedziny (obszaru, procesu, projektu, zadania itp.), w ramach której występują negocjacje jako narzędzie, w pełnym ich zakresie (zasadnicza rola),

- kierownik (szef) zespołu (główny negocjator) - steruje procesem negocjacji,

- analityk informacji - może także pełnić rolę rzecznika zespołu i (lub) protokolanta czy sekretarza (jeśli jest to niezbędne),

- obserwator procesu (analityk zachowań) - skoncentrowany na behawioralnych aspektach procesu negocjacji,

- ekspert (doradca) merytoryczny - w zakresie zagadnień rozważanych w negocjacjach (bezpośrednio związanych z ich przedmiotem i dodatkowych),

- członek zespołu - osoba niespełniająca żadnej z wymienionych ról, lecz zajmująca się wybranymi zagadnieniami merytorycznymi (,szara eminencja”). 
Tabela 1. Przykładowe typologie ról w zespole negocjacyjnym

\begin{tabular}{|l|l|}
\hline \multicolumn{1}{|c|}{ Autor } & \multicolumn{1}{c|}{ Wyróżnione role } \\
\hline $\begin{array}{l}\text { M. Watkins } \\
\text { [2005, s. 182-183] }\end{array}$ & wewnętrzne (z firmy) i zewnętrzne (doradców) \\
\hline $\begin{array}{l}\text { P.J. Dąbrowski } \\
\text { [1991, s. 62-63] }\end{array}$ & $\begin{array}{l}\text { główny negocjator, decydent, ekspert merytoryczny, ekspert uwarunkowań, } \\
\text { obserwator procesu }\end{array}$ \\
\hline $\begin{array}{l}\text { Z. Nęcki } \\
\text { [2000, s. 191-192] }\end{array}$ & lider, protokolant, słuchacz, krytyk, kontroler \\
\hline $\begin{array}{l}\text { W.B. Jankowski } \\
\text { i T.P. Sankowski } \\
\text { [1995, s. 28] }\end{array}$ & $\begin{array}{l}\text { lider, prowadzący rozmowy, twardy negocjator, przyjazny negocjator, eks- } \\
\text { pert-specjalista, sekretarz, inni }\end{array}$ \\
\hline $\begin{array}{l}\text { P. Casse } \\
\text { [1996, s. 70 i nast.] }\end{array}$ & $\begin{array}{l}\text { przewodniczący (główny negocjator), faktyczny negocjator, negocjator } \\
\text { analityk, negocjator rozjemca, negocjator intuicyjny }\end{array}$ \\
\hline $\begin{array}{l}\text { A.N. Schoonmaker } \\
\text { [1989, s. 216-228] }\end{array}$ & $\begin{array}{l}\text { przełożony (zleceniodawca), kierownik, rzecznik, ,twardy facet”,,,sympa- } \\
\text { tyczny facet”, analityk zachowan, analityk informacji, doradca specjalistyczny }\end{array}$ \\
\hline $\begin{array}{l}\text { A. Fowler } \\
\text { [2001, s. 51-52] }\end{array}$ & $\begin{array}{l}\text { lider, badacz źródeł, koordynator, indywidualista, analityk, detalista, wdro- } \\
\text { żeniowiec, członek drużyny, specjalista (na podstawie ról zespołowych } \\
\text { M. Belbina [2002]) }\end{array}$ \\
\hline
\end{tabular}

Źródło: opracowanie własne.

Wszystkie role mogą być spełniane przez pracowników firmy, natomiast dla doradców możliwe do realizacji są w zasadzie tylko role eksperta oraz ewentualnie analityka informacji i obserwatora. W szczególności nie powinni oni spełniać ról kierowniczych. Niektóre role mogą być też pełnione częściowo nie przez członków zespołu, ale przez pracowników sztabowych i kierowników funkcjonalnych, w szczególności w zakresie analizy i przetwarzania niezbędnych informacji oraz fachowego doradztwa, przed, w trakcie i po negocjacjach.

\section{Zasady zlecania i podziału zadań}

Celem omawianych dalej działań jest konkretyzacja wcześniejszych ustaleń, tj. sprecyzowanie zadań i uprawnień reprezentantów firmy w negocjacjach - indywidualnych lub członków zespołu (i innych pracowników zaangażowanych w negocjacje). Dla realizacji tego celu niezbędne są następujące działania organizacyjne:

- określenie i zlecenie zadań do realizacji,

- ustalenie i przydzielenie adekwatnych zakresów uprawnień i odpowiedzialności,

- opracowanie i dostarczenie (ewentualnych) instrukcji negocjacyjnych. 
W efekcie realizacji tych działań (i ustaleń poprzedniego etapu) następuje merytoryczne i formalne określenie miejsca i roli zasobów ludzkich (ich alokacja) w negocjacjach.

Zakresy zadań negocjatorów i ich współpracowników ustala się, po pierwsze, biorąc pod uwagę czynności określone poprzez zasady sztuki negocjacji, ujęte w modelowych zestawieniach ról w zespole negocjacyjnym (tabela 2), a po drugie, z uwzględnieniem obowiązków pracowników, wynikających z zajmowania określonych stanowisk pracy w firmie i kompetencji wymaganych do realizacji ich funkcji.

Uwzględniając cechy negocjacji w firmie i ich rodzaje ze względu na częstotliwość występowania (rutynowe, powtarzalne versus sporadyczne, bezprecedensowe), celowe jest wyróżnienie dwóch form zlecania zadań reprezentantom:

- czynnościowo - w sposób stały, powtarzalny, jako elementy zakresów zadań, zwykle dla negocjacji rutynowych (powtarzalnych), np. handlowca z klientem,

- sytuacyjnie, tj. poprzez doraźne zlecenia (zależnie od potrzeb), gdy mamy do czynienia ze sporadyczną czy bezprecedensową sytuacją negocjacyjną, np. w negocjacjach z inwestorem strategicznym.

W przypadku członków zespołu będących pracownikami firmy stosuje się obie formy, z przewagą pierwszej, natomiast dla ekspertów zewnętrznych - głównie drugą. Używa się także sposobów kombinowanych, tj. zleca zadania sytuacyjnie w przypadkach rutynowych, np. celem uzupełnienia o dodatkowe czynności, przy konieczności zastępstw, uzupełnienia składu zespołu o eksperta w zakresie nietypowych zadań itp., oraz przydziela (dodaje) zadania powtarzalne w negocjacjach sporadycznych, np. rutynowe obowiązki związane z reprezentowaniem firmy, typowe prace analityczne itp.

Standardową formą ustalania i zlecania zadań, uprawnień i odpowiedzialności pracownikom firmy w negocjacjach jest zakres czynności (karta zadań), ewentualnie polecenie doraźne - dla drugiego ze sposobów ich przydzielania. Zakres ten służy formalizacji zadań. Oprócz szczegółowego wykazu obowiązków danego stanowiska określa również jego stosunki z innymi, środki będące w jego dyspozycji przy realizacji zadań i wymagane kwalifikacje [Nalepka i Kozina 2007, s. 32].

$\mathrm{Z}$ kolei instrukcja negocjacyjna dostarcza niezbędnych w danej sytuacji wskazań co do sposobu realizacji zadań, współpracy w zespole, dysponowania zasobami, wykorzystania informacji i środków finansowych itd. Dokładnie określa i uzasadnia, co i jak należy lub nie należy robić. Stanowi odmianę instrukcji organizacyjnej, czyli jest „opartym na logice i doświadczeniu przepisem podającym sposób realizacji określonych zadań. Porządkuje i reguluje przebieg typowych procesów i procedur działania w poszczególnych obszarach funkcjonowania firmy, w określonych sytuacjach organizacyjnych" [Nalepka i Kozina 2007, s. 35]. 
Przy zlecaniu stałych, powtarzalnych czynności instrukcje negocjacyjne są uszczegółowieniem kart zadań, a dla zadań niepowtarzalnych zawierają także określenie zadań, uprawnień i odpowiedzialności (chyba że te są ujęte w specjalnych kartach zleceń lub umowach z ekspertami zewnętrznymi).

Tabela 2. Podział zadań w zespole negocjacyjnym ze względu na pełnione role

\begin{tabular}{|c|c|}
\hline Rola & Zadania \\
\hline $\begin{array}{l}\text { Przełożony } \\
\text { (decydent, } \\
\text { zlecenio- } \\
\text { dawca) }\end{array}$ & $\begin{array}{l}\text { Ponoszenie odpowiedzialności za osiągnięcie jak najlepszego wyniku ze względu } \\
\text { na cele negocjacji i firmy jako całości } \\
\text { Podejmowanie decyzji o rozpoczęciu negocjacji } \\
\text { Wyznaczanie (powoływanie) kierownika zespołu i zatwierdzanie składu zespołu } \\
\text { Delegowanie kierownikowi zadań i uprawnień decyzyjnych } \\
\text { Nadzorowanie jego działań oraz przebiegu negocjacji } \\
\text { Zatwierdzanie kluczowych decyzji w procesie negocjacji, zwłaszcza w zakresie } \\
\text { istotnych ustępstw i podejmowania zobowiązań } \\
\text { Formułowanie ostatecznego projektu umowy (ratyfikowanej później na wyższym } \\
\text { szczeblu) } \\
\text { Dokonywanie niezbędnych interwencji lub zaangażowania się (jeśli sytuacja tego } \\
\text { wymaga) } \\
\text { Pełnienie roli szefa zespołu w przypadku bezpośredniego udziału w negocjacjach } \\
\text { Ocenianie efektywności negocjacji (ocena zewnętrzna) }\end{array}$ \\
\hline $\begin{array}{l}\begin{array}{l}\text { Kierownik } \\
\text { (szef) }\end{array} \\
\text { zespołu } \\
\text { (główny } \\
\text { negocjator) }\end{array}$ & $\begin{array}{l}\text { Określanie celów cząstkowych (szczegółowych) oraz strategii i technik negocjacji } \\
\text { Identyfikowanie i pozyskiwanie zasobów niezbędnych do prowadzenia negocjacji } \\
\text { Określanie czasu i miejsca negocjacji } \\
\text { Ustalanie składu zespołu (dobór reprezentantów) } \\
\text { Wyznaczanie ról i zadań członkom zespołu } \\
\text { Składanie propozycji drugiej stronie, dokonywanie ustępstw i podejmowanie } \\
\text { zobowiązań } \\
\text { Koordynowanie pracy zespołu } \\
\text { Kontrolowanie przebiegu negocjacji } \\
\text { Ocenianie ich efektywności (ocena wewnętrzna) }\end{array}$ \\
\hline $\begin{array}{l}\text { Analityk } \\
\text { informacji }\end{array}$ & $\begin{array}{l}\text { Organizowanie i kontrolowanie procesów komunikowania się w negocjacjach } \\
\text { Przygotowywanie (pozyskiwanie, przetwarzanie, porządkownie itp.) niezbędnych } \\
\text { danych } \\
\text { Opracowywanie analiz sytuacji negocjacyjnych i założeń do planów negocjacji } \\
\text { Przygotowywanie prezentacji stanowiska i ofert zespołu } \\
\text { Analizowanie ofert i kontrofert oraz przyczyn i skutków ich przyjmowania } \\
\text { (odrzucania) } \\
\text { Przygotowywanie (kontr)argumentów oraz pytań do drugiej strony i odpowiedzi } \\
\text { na jej pytania } \\
\text { Ocenianie potencjalnych korzyści i strat zespołu } \\
\text { Wspomaganie kierownika, a zwłaszcza ostrzeganie go przy dochodzeniu do } \\
\text { granicy ustępstw } \\
\text { Informowanie o stanowisku i opiniach zespołu (jako jego rzecznik) } \\
\text { Sporządzanie sprawozdań i protokołów z przebiegu negocjacji (jako protokolant) }\end{array}$ \\
\hline
\end{tabular}


cd. tabeli 2

\begin{tabular}{|l|l|}
\hline \multicolumn{1}{|c|}{ Rola } & \multicolumn{1}{c|}{ Zadania } \\
\hline $\begin{array}{l}\text { Obserwator } \\
\text { procesu } \\
\text { (analityk } \\
\text { zachowań) }\end{array}$ & $\begin{array}{l}\text { Obserwowanie zachowań uczestników negocjacji (obydwu zespołów), stosowa- } \\
\text { nych technik, chwytów, ofert, argumentów pytań itp } \\
\text { Dokonywanie interpretacji tych zachowań oraz wyciąganie z nich i przekazywa- } \\
\text { nie wniosków } \\
\text { Doradzanie i pomaganie kierownikowi i innym członkom zespołu w lepszym } \\
\text { zrozumieniu przebiegu negocjacji } \\
\text { Ocenianie skuteczności działań zespołu i wskazywanie ewentualnych korekt } \\
\text { w zakresie zachowań i narzędzi negocjacji } \\
\text { Tworzenie rzetelnego i trafnego obrazu sytuacji (nieobciążenie odpowiedzialno- } \\
\text { ścią za decyzje) }\end{array}$ \\
\hline $\begin{array}{l}\text { Ekspert } \\
\text { (doradca) } \\
\text { meryto- } \\
\text { ryczny }\end{array}$ & $\begin{array}{l}\text { Wspieranie zespołu poprzez dostarczanie mu fachowych porad oraz niezbędnej } \\
\text { wiedzy specjalistycznej, dotyczącej przedmiotu negocjacji oraz pomocniczej (na } \\
\text { temat zagadnień dodatkowych, np. finansowych, prawnych, etycznych itp.) } \\
\text { Wspomaganie zespołu w doborze efektywnych narzędzi (strategii i technik) } \\
\text { negocjacyjnych } \\
\text { Pozyskiwanie, porządkowanie i dostarczanie niezbędnych danych oraz analizo- } \\
\text { wanie i prognozowanie sytuacji negocjacyjnych (we współpracy z analitykiem } \\
\text { informacji) } \\
\text { Tworzenie nowych rozwiązania rozważanych problemów } \\
\text { Określanie granice możliwości, a zwłaszcza potencjalnych ustępstw }\end{array}$ \\
$\begin{array}{l}\text { Niespełnianie żadnej szczególnej roli, lecz zajmowanie się odpowiednimi kwe- } \\
\text { stiami merytorycznymi w zakresie posiadanych kompetencji, np. technicznymi, } \\
\text { prawnymi (po części ekspert i analityk informacji w zakresie tych zagadnień }\end{array}$ \\
\hline $\begin{array}{l}\text { Członek } \\
\text { zespołu }\end{array}$
\end{tabular}

Źródło: opracowanie własne.

Jako uszczegółowienie (uzupełnienie) omówionych narzędzi (bądź niezależnie, czy alternatywnie) stosowane są plany trwale obowiązujące, a zwłaszcza procedury oraz wytyczne i reguły. Podobnie jak wcześniej wymienione dokumenty, procedura jest elementem planu negocjacji [Walker i Harris 1995, s. 73-79], stanowi „porządek, w jakim zadania będą spełniane, jest procesem, w którym zasoby są przemieniane w rezultaty, każdy jej krok powinien zawierać: określenie tego, co ma być zrobione, wymiar czasowy (terminy początku i zakończenia), osobę (lub osoby) odpowiedzialne" [Bittel 1989, s. 89]. Opracowanie procedury wymaga więc wcześniejszego określenia zasobów. Jej zakres może być szeroki - stanowi wtedy ogólny plan negocjacji [Mastenbroek 1995, s. 97-101] lub wąski, np. ogranicza się do negocjacji formalnych [Fowler 2001, s. 66], o dużym „ciężarze gatunkowym”, np. zbiorowych [Kennedy 1998, s. 195-197]. Do jej tworzenia można stosować powszechnie znane techniki graficzne identyfikacji, analizy i projektowania procesów. Do negocjacji przydatne są zwłaszcza dwa narzędzia tego rodzaju, tj.:

- wykres Hijmansa, inaczej tablica kompetencyjna [Marżantowicz 1973]. $\mathrm{W}$ jego wierszach umieszcza się funkcje (działania) realizowane w negocjacjach, 


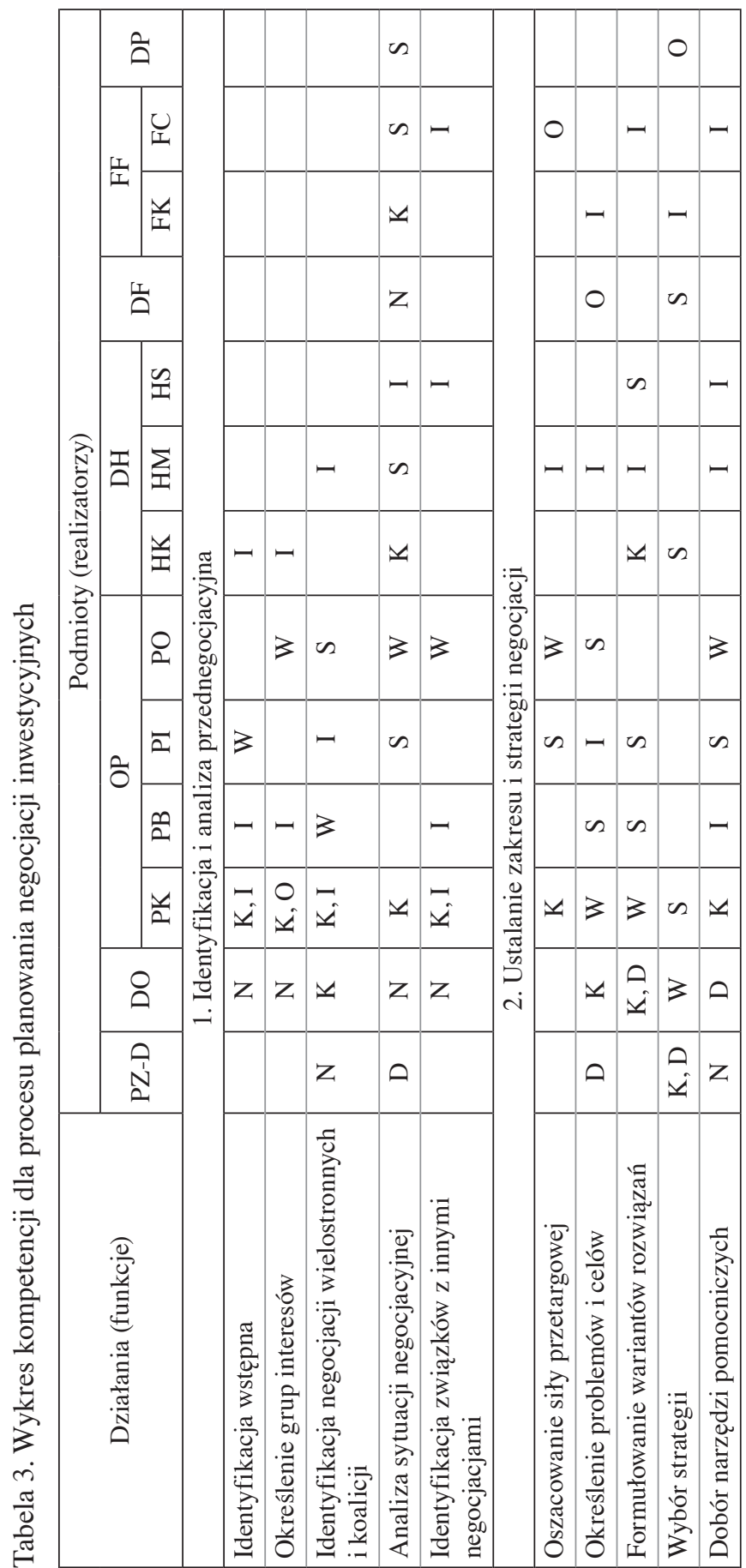




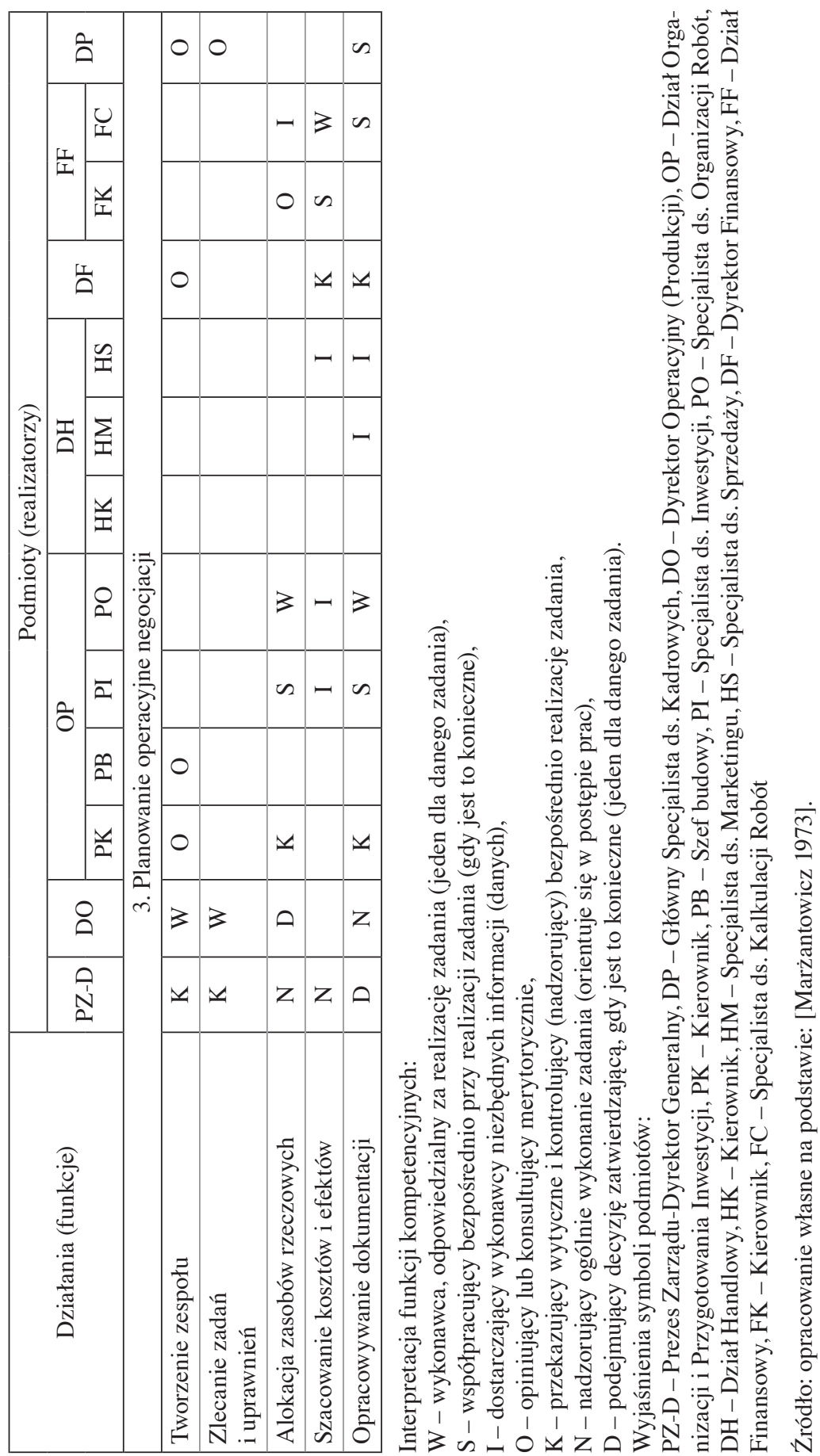


a w kolumnach podmioty odpowiedzialne za ich realizację (członków zespołu negocjacyjnego i ich współpracowników). Na przecięciu wierszy i kolumn zaznacza się (symbolami) funkcje kompetencyjne tych podmiotów odzwierciedlające charakter ich udziału w realizacji zadań. Uzyskuje się w ten sposób syntetyczne i przejrzyste ujęcie miejsca i roli wszystkich pracowników zaangażowanych w negocjacje (tabela 3);

- wykres Clarka [Czekaj 1975], w którym zaznacza się kolejne działania jako fazy procedury negocjacji, realizowane przez poszczególne podmioty (ujęte w kolumnach), z określeniem powiązań pomiędzy tymi działaniami i przekazywanych informacji. Planowany przebieg negocjacji można także zilustrować za pomocą diagramu (przebiegu) procesu, który w formie graficznej przedstawia kolejne działania w procesie wraz z relacjami między nimi i zaznaczeniem ich wykonawców. Dodatkowo może obrazować: rodzaje tych działań, stany wejścia i wyjścia procesu, jego zasoby itp.

Dodatkową kwestią jest dobór bodźców motywacyjnych dla reprezentantów firmy w negocjacjach (udział ekspertów zewnętrznych jest regulowany w formie umów, określających ich wynagrodzenie). Najogólniej stosuje się dwie grupy bodźców:

- materialne - wynagrodzenie, które w zależności od formy przydziału zadań stanowi albo część wynagrodzenia zasadniczego za realizację zadań ujętych w ich formalnym zakresie, albo jednorazową zapłatę za zlecone zadanie, z uwzględnieniem ewentualnych premii, uzależnionych głównie od oceny sprawności działania i (lub) wyniku negocjacji.

- niematerialne - możliwość reprezentowania firmy, podniesienia kwalifikacji, powierzenie nowych, samodzielnych i (lub) twórczych zadań, satysfakcja z pracy w zespole, partycypacja w planowaniu negocjacji i podejmowaniu decyzji itp.

\section{Zasady delegowania uprawnień decyzyjnych}

Zakres uprawnień dla reprezentanta lub zespołu (jego szefa) może obejmować: określanie, weryfikowanie i (lub) modyfikowanie celów negocjacji, dobór sposobów ich prowadzenia (strategii i narzędzi szczegółowych), dysponowanie różnego rodzaju zasobami, podejmowanie decyzji w zakresie poszczególnych kwestii, w tym dokonywanie zobowiązań i ustępstw, a nawet zawieranie porozumienia.

Przy ustalaniu tego zakresu należy stosować następujące zasady stworzone w ramach techniki zarządzania przez delegowanie uprawnień (kompetencji decyzyjnych), której istotą jest przekazywanie pracownikom na niższych szczeblach zarządzania części formalnej władzy i odpowiedzialności za wykonanie zadań (tutaj w negocjacjach): 
- precyzyjnego i jednoznacznego określenia zakresu zadań i kompetencji,

- kompletności delegowania uprawnień niezbędnych w danej sytuacji,

- adekwatności uprawnień, tj. ich równowagi z zakresem zadań i odpowiedzialności,

- przekazywania całościowych zadań (w pełnym zakresie roli negocjacyjnej),

- trwałego przekazywania zadań tego samego rodzaju dla tych samych pracowników.

- dostosowania kompetencji do potencjału i możliwości pracowników,

- dostarczenia pełnej informacji (instrukcji) o przekazywanym zadaniu,

- zapewnienie efektywnej komunikacji zwrotnej dla konsultacji i sprawozdań,

- wspomagania w rozwiązywaniu problemów przy realizacji zadań i uprawnień [Metody sprawnego zarzadzania... 1997, s. 173-181; DuBrin 1986, s. 255-26; Zimniewicz 1991, s. 59-65].

Przypisanie odpowiedzialności sprowadza się do tego, że wybrana osoba (zespół): musi ponosić odpowiedzialność, mieć władzę, posiadać kontrolę nad planami i zasobami, odpowiadać za rezultaty [Bittel 1989, s. 89].

Problem przydziału uprawnień w negocjacjach można rozwiązać, wykorzystując kategorie teorii agencji [Kozina 2012, s. 82-86], a w szczególności propozycję R. Fishera i W.H. Davisa [1999], którzy stwierdzili, że każdy mocodawca (przełożony wyższego szczebla) staje przed wyzwaniem, jak instruować agenta (reprezentanta firmy w negocjacjach lub szefa zespołu negocjacyjnego), aby zwiększać możliwości osiągnięcia przez niego jak najlepszych rezultatów negocjacji. Autorzy koncentrują się na wzbudzającej najwięcej obaw kwestii uprawnień reprezentanta do podejmowania zobowiązań w imieniu mocodawcy. Standardowe pytanie, zadawane przez większość mocodawców, brzmi: ,jak wiele uprawnień powinienem przekazać agentowi?”. Podejście to (nazwane ,tradycyjnym”) jest bezproduktywne. Przy określeniu uprawnień występuje, z jednej strony, wiele uwarunkowań, pod wpływem których mocodawca mógłby być skłonny do przydzielenia agentowi szerokich uprawnień, np. przy transakcjach o małej stawce, dotyczących pojedynczej kwestii, w przypadku nieobecności mocodawcy lub w zakresie których oba podmioty posiadają znaczne, wspólne doświadczenia i mocodawca obdarza agenta dużym zaufaniem. Z drugiej strony występują przypadki, w których mocodawca powinien przyznać agentowi wąski zakres uprawnień, tzn. gdy jest on niedoświadczony - sytuacja i (lub) stanowisko są mu nieznane - lub występuje znaczna rozbieżność interesów obu podmiotów.

Tradycyjne podejście do przyznawania agentowi prawa podejmowania zobowiązań stwarza problemy mocodawcy i agentowi, a nawet negocjatorowi zewnętrznemu. Prowadzi oba podmioty do przyjęcia wiążących postanowień zbyt wcześnie, tzn. bez dostatecznego wykorzystania możliwości uczenia się poprzez negocjacje. Aby uniknąć tych problemów, należy zmienić sposób podejścia, biorąc pod uwagę 


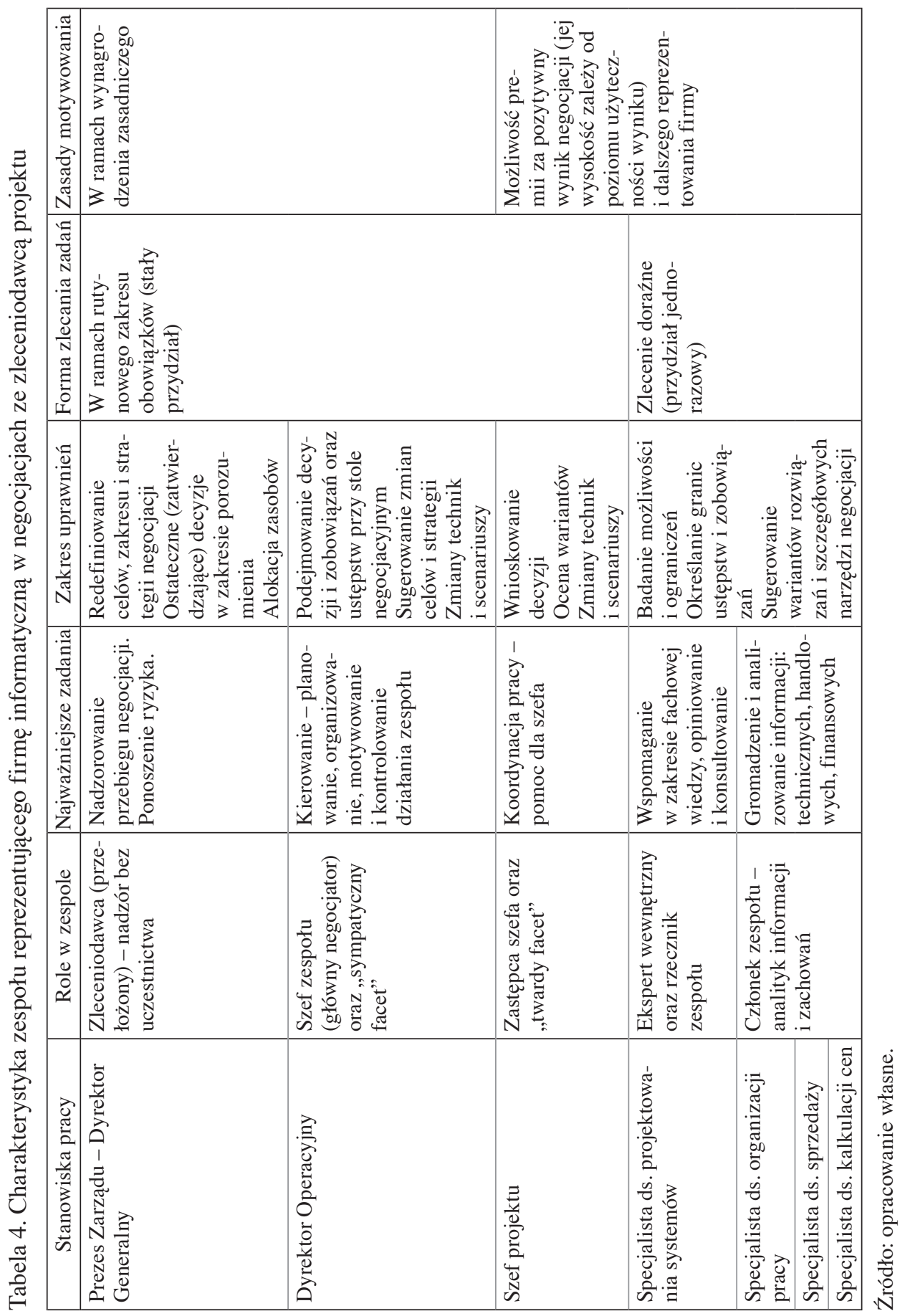


dodatkowo: uczenie się i koordynację (przekazywania uprawnień w trakcie negocjacji). Bardziej użyteczne niż tradycyjne jest pytanie o zakres uprawnień reprezentanta (nazwane ,alternatywnym”): „, jaki sposób należy dostosowywać zakres uprawnienia agenta do podejmowania zobowiązań podczas przebiegu negocjacji?". Generalnie mocodawca nie powinien przyznawać agentowi uprawnień w zakresie kwestii merytorycznych na początku negocjacji oraz zwiększać stopniowo zakres tych uprawnień w procesie negocjacji, proporcjonalnie do stopnia uczenia się przez agenta (poszerzania zakresu posiadanych danych i stopnia rozpoznania sytuacji ze strategicznego i taktycznego punktu widzenia) oraz dzielenia się uzyskaną wiedzą z mocodawcą. Prawa do podejmowania zobowiązań w zakresie zawierania porozumienia powinny być przyznawane dopiero $w$ drugiej kolejności, a na początku negocjacji agent powinien mieć możliwość kształtowania i rozwoju efektywnego procesu negocjacji. Mocodawca powinien skoncentrować się na dostarczeniu mu zestawu pisemnych instrukcji w zakresie interesów i priorytetów, określić jednoznaczne oczekiwania co do jakości i częstotliwości jego raportów oraz sformułować zasady ujawniania (lub nie) przez niego informacji.

Korzyści podejścia alternatywnego to ograniczenie lub eliminowanie większości problemów podejścia tradycyjnego. Mocodawca może kształtować działania i uprawnienia agenta, obserwując i oceniając przebieg negocjacji. Zmniejsza się obawy, że agent osiągnie niekorzystne rozwiązanie. Przez stopniowe zwiększanie jego uprawnień, mocodawca ogranicza ryzyko wynikające ze zbytniego ograniczania jego elastyczności i wiarygodności. Zachęca go to do opartego na interesach, a nie pozycyjnego, prowadzenia negocjacji, co pozwala osiągnąć lepsze rezultaty. Agent zostaje pozbawiony uprawnień, gdy jest to najbardziej odpowiednie z uwzględnieniem taktycznym, we wczesnej fazie negocjacji, tj. podczas wymiany informacji i burzy mózgów przy tworzeniu wariantów. Otrzymuje większy zakres uprawnień przy dochodzeniu do końcowego porozumienia. Negocjator zewnętrzny ma poczucie bezpieczeństwa, że negocjuje z właściwą osobą, zdolną do wiążących wypowiedzi w stosownym momencie. Prawdopodobieństwo przedstawienia przez niego dodatkowych żądań jest dużo mniejsze [Fisher i Davis 1999].

W tabeli 4 przedstawiono przykładową charakterystykę zespołu negocjacyjnego zorganizowanego zgodnie z omówionymi zasadami.

\section{Podsumowanie}

Celem artykułu było ukazanie metodologicznych aspektów planowania negocjacji w firmie. Przedstawiona propozycja organizowania zespołu negocjacyjnego jako istotnego etapu ich planowania może stanowić użyteczne narzędzie 
identyfikacji i analizy praktycznych przypadków negocjacyjnych. Uniwersalność i kompleksowość przyjętej koncepcji metodycznej czyni ją adekwatną do wszelkiego rodzaju negocjacji prowadzonych w firmie. Przy organizowaniu zespołu negocjacyjnego należy stosować przedstawione rozwiązania modelowe, adaptując je do specyficznych uwarunkowań negocjacji.

Przedstawiona koncepcja jednak wymaga uszczegółowienia i udoskonalenia, głównie pod kątem wzbogacenia szczegółowych narzędzi metodycznych (zasad i metod), zwłaszcza dotyczących analizy kompetencji merytorycznych reprezentantów firmy, koordynowania działań członków zespołu w procesie negocjacji (szczególnie ustalania zakresu współpracy i form kontaktów) oraz opracowywania sposobów monitorowania tych działań i analizy ich efektów. Wymagana jest także empiryczna weryfikacja proponowanej koncepcji w badaniach porównawczych dotyczących różnorodnych negocjacji w przedsiębiorstwie.

\section{Literatura}

Barrett P. [1994], Tworzenie zespołu [w:] Praktyka kierowania. Jak kierować soba, innymi i firma, red. D. M. Stewart, PWE, Warszawa.

Belbin M. [2002], Twoja rola w zespole, Wydawnictwo GWP, Gdańsk.

Bittel L.R. [1989], Krótki kurs zarzązania, Wydawnictwo Naukowe PWN - McGraw-Hill Book Company, Warszawa-Londyn.

Brooks E., Odiorne G.S. [1984], Managing by Negotiations, Van Nostrand Reinhold Company Inc., New York.

Casse P. [1996], Jak negocjować? Wydawnictwo Zysk i S-ka, Poznań.

Czekaj J. [1975], Wykres Clarka w badaniu i usprawnianiu pracy administracyjnej metoda analizy wrażliwości, „Organizacja-Metody-Technika”, nr 7.

Dąbrowski P.J. [1991], Praktyczna teoria negocjacji, Sorbog, Warszawa.

Doskonalenie struktury organizacyjnej [1991], red. A. Stabryła, PWE, Warszawa.

DuBrin A.J. [1986], Essentials of Management, South-Western Publishing Co., Cincinnati.

Fisher R., Davis W.H. [1999], Authority of an Agent. When is Less Better? [w:] Negotiating on Behalf of Others. Advice to Lawyers, Business Executives, Sports Agents, Diplomats, Politicians and Everybody Else, red. R.H. Mnookin, L.E. Susskind, Thousand Oaks, Sage Publications, California.

Fowler A. [2001], Jak skutecznie negocjować, Petit, Warszawa.

Hiltrop J.M., Udall S. [1995], The Essence of Negotiation, Prentice Hall, London.

Jankowski W.B., Sankowski T.P. [1995], Jak negocjować, Centrum Informacji Menedżera, Warszawa.

Jaques D. [1992], Learning in Groups, Kogan Press, London.

Kennedy G. [1998], Negocjator, Studio EMKA, Warszawa.

Kozina A. [2001], Potencjat sprawnego negocjatora [w:] Kapitat intelektualny - dylematy $i$ wyzwania, red. A. Pocztowski, Wyższa Szkoła Biznesu - National Louis University w Nowym Sączu, Nowy Sącz. 
Kozina A. [2012], Planowanie negocjacji w przedsiębiorstwie, Wydawnictwo Uniwersytetu Ekonomicznego w Krakowie, Kraków.

Kozina A. [2014], Negocjacje w przedsiębiorstwie z perspektywy zarzadzania projektem, „Modern Management Review”, vol. XIX, nr 1(21).

Lewicki R.J., Saunders D.M., Barry B., Minton J.W. [2005], Zasady negocjacji. Kompendium wiedzy dla trenerów i menedżerów, Dom Wydawniczy Rebis, Poznań.

Mannix E.A. [2005], Strength in Numbers: Negotiating as a Team, „Harvard Business Review", May.

Marżantowicz T. [1973], Systemowe cechy przedmiotowej organizacji kierownictwa, „Problemy Organizacji”, nr 4.

Mastenbroek W. [1996], Negocjowanie, Wydawnictwo Naukowe PWN, Warszawa.

Metody sprawnego zarzadzania. Planowanie, organizowanie, motywowanie, kontrola [1997], red. H. Bieniok i Zespół, Agencja Wydawnicza Placet, Warszawa.

Nalepka A., Kozina A. [2007, Podstawy badania struktury organizacyjnej, Wydawnictwo Akademii Ekonomicznej w Krakowie, Kraków.

Nęcki Z. [2000], Negocjacje w biznesie, Antykwa, Kraków.

Rządca R. [2003], Negocjacje w interesach, PWE, Warszawa.

Schoonmaker A.N. [1989], Negotiate to Win. Gaining the Psychological End, Prentice Hall, Englewood Cliffs, New Jersey.

Thompson L.L. 2001], The Mind and Heart of The Negotiator, Prentice Hall, Upper Saddle River, N.J.

Walker M.A., Harris G.L. [1995], Negotiations. Six Steps To Success, Prentice Hall, New Jersey.

Watkins M. [2005], Sztuka negocjacji w biznesie. Innowacyjne podejście prowadzace do przełomu, Helion, Gliwice.

Zbiegień-Maciąg L. [2001], Taktyki i techniki negocjacyjne, Wydawnictwa AGH, Kraków. Zimniewicz K. [1991], Techniki zarzadzania, PWE, Warszawa.

\section{Organising a Negotiating Team}

The objective of the paper is to systematise the most important problems connected with organising a team representing a company within different types of negotiations (either internal or external ones) as well as to present the principles (recommendations, indications and rules) for solving such problems. Creating a negotiating team constitutes one of the most important activities performed within the process of negotiation planning in a company. The following problems concerning the organisation of a negotiating team are described along with the principles for solving those problems: 1) making decisions on appointing a negotiating team, 2) selecting its organisational form, 3) determining its size, 4) stating criteria for selecting members, 5) designating team roles, 6) assigning tasks and their division between team members, 7) delegating decision-making powers.

Keywords: negotiations in a company, negotiating team, negotiations operational planning, organising a negotiating team. 